\title{
Awareness of fishermen for managing fish sanctuary in some selected areas of Jamalpur District in Bangladesh
}

\author{
L Akter, MJ Hoque*, MA Kashem, TD Nath \\ Department of Agricultural Extension Education, Bangladesh Agricultural University, \\ Mymensingh 2202, Bangladesh
}

\begin{abstract}
The purposes of the study were to determine the extent of awareness of the fishermen in managing fish sanctuary and to find out the relationships between the extent of awareness of the fishermen and their selected characteristics. Data were collected from 90 purposively selected fishermen (out of 105) from Ghosherpara Union of Melandah Upazila Under Jamalpur District. A pre-tested and structured interview schedule was used to collect data from the fishermen during the period of 19 March to 30 March, 2013. The findings indicated that majority of the respondents (74.5 percent) had medium awareness and 25.5 percent having high awareness. Out of ten selected characteristics, the fishermen's age, level of education, fish culture experience, communication exposure and agricultural knowledge on fish sanctuary showed significant positive relationships with their extent of awareness in managing fish sanctuary. On the other hand, household size, farm size, annual family income, training exposure and credit received had no significant relationships with their extent of awareness in managing fish sanctuary. So, to increase awareness of the fishermen in managing sanctuary, proper guidance and strengthening fisheries extension service should be done by fisheries extension workers/ upazila fisheries officer through arranging different activities including training, field visit or using different communication media etc.
\end{abstract}

Key words: Awareness, fishermen and fish sanctuary.

Progressive Agriculturists. All rights reserve

*Corresponding Author: manikdaee@gmail.com

\section{Introduction}

Bangladesh is a land of river. Many rivers, canals, ponds, beels are situated everywhere like spider web in our country. The abundance of water resources, suitable environment, favorable climatic condition and soil made Bangladesh ideal place for fish production. Fish and fisheries sector play an immensely important role on the socio-economic development of Bangladesh from time immemorial and it is the part of our cultural heritage. Fisheries sector contributes about $3 \%$ of the total export earning, $3.74 \%$ to GDP and $22.23 \%$ to agricultural sector (DoF, 2010).
Bangladesh is a small country in terms of area covering 1, 47,570 sq. $\mathrm{km}$ but large number of population comprising about 158,570,535 people (BBS, 2011). The population is increasing day by day as a result the demand of fish also increasing. Annual fish production was 2,701, 370 MT in 2008-09 fiscal years (DoF, 2010). Fish and fisheries sector play a vital role in the national economy as well as in meeting up animal protein demand for the increased population of the country. Most of the people in the country depend on fish as the main source of protein. Fish, which is rich in 
high quality protein, lipid and minerals, is nutritionally better to meat (Saha, 2004).

In Bangladesh, many important fish species are already extinct and some are becoming extinct. Fish sanctuary is done mainly to protect the endangered fish species. So that, the existing fish species does not extinct and endangered fish species can safe from endangered. Deficit of fish production is a great problem as the pressure of population is massive. Fish production can be increased by managing fish sanctuary through fishermen if they are fully aware of it. Fish sanctuaries are available but people are not aware about this. They catch fishes from sanctuary due to lack of awareness about the importance of sanctuary. As a result of these, there is no fish diversity and existing fish species are endangered already.

Hence considering all the facts, the study was undertaken to investigate awareness of the fishermen towards managing fish sanctuary and formulated objectives to determine the extent of awareness of the fishermen in managing fish sanctuary, describe the selected characteristics of the fishermen and explore the relationships between the extent of awareness of the fishermen and their selected characteristics.

\section{Methodology}

\section{Study area, population and sampling}

Selection of the study area is very important for fish conservation. The purpose would, therefore, be better served in an area where there is a good concentration of fish conservation. Therefore, the study was conducted in Ghosherpara union of Melandah upazila under Jamalpur district where fish sanctuary is the major practice. The fishermen who were involved in fish sanctuary of this union were considered as the population of the study. In Ghosherpara union, 105 such fishermen were found from which 90 fishermen were considered as the sample of the study. An interview schedule was used as the data-gathering instrument containing both open and closed form questions. Data were collected from 19 to 30 March,
2013 using random sampling method. Based on pretest, necessary corrections, alterations and modifications were made before finalizing the interview schedule.

\section{Selection and measurement of explanatory and focus variables}

Ten selected characteristics of the fishermen were the explanatory variables of the study. These were age, level of education, household size, farm size, annual family income, fish culture experience, training exposure, credit received, communication exposure and agricultural knowledge on fish sanctuary. Scale was developed to measure the explanatory variables which were based on raw data (Table 1).

Awareness of the fishermen in managing fish sanctuary was the focus variable of the study. This variable was measured through a 5-point Rating scale. Twenty statements on various aspects of fish sanctuary were asked to the fishermen. There were five options to response a statement, namely 'very high', 'high', 'moderate', 'low' and 'not at all' with a corresponding score of 4, 3, 2, 1 and 0 respectively. A respondent was asked to indicate his/her information source regarding a statement by selecting the appropriate option. The awareness score of a respondent was computed by summing the scores for his responses to all the statements. Hence, scores of a respondent could range from 0 to $80 ; 0$ indicating no awareness and 80 indicating very high awareness towards managing fish sanctuary.

Awareness Index (AI): $A_{v h} \times 4+A_{h} \times 3+A_{m} \times 2+A_{l}$ $\mathrm{x} 1+\mathrm{A}_{\mathrm{n}} \times 0$

Where,

$\mathrm{A}_{\mathrm{vh}}$ x $4=$ Number of respondents with 'very high' awareness

$A_{h} \times 3=$ Number of respondents with 'high' awareness $A_{m} \times 2=$ Number of respondents with 'moderate' awareness

$A_{1}$ x $1=$ Number of respondents with 'low' awareness $A_{n} \times 0=$ Number of respondents with 'not at all' awareness 


\section{Data analysis}

Data were analyzed in accordance with objectives of the study. Various statistical measures such as range, mean, number percentage, standard deviations and rank order were used to describe the selected characteristics of the respondents of the study area. In order to find out the relationship between the individual characteristics of fishermen and awareness, Pearson's Product Moment Correlation Co-efficient (r) was computed.

Table 1. Selected characteristics of the fishermen

\section{Result and discussion}

\section{Selected characteristics of the fishermen}

Awareness of the fishermen in managing fish sanctuary was affected by ten selected characteristics of the fishermen such as age, level of education, household size, farm size, annual family income, fish culture experience, training exposure, credit received, communication exposure and knowledge in managing fish sanctuary which have been presented in Table 1 .

\begin{tabular}{|c|c|c|c|c|c|c|c|}
\hline \multirow[b]{2}{*}{ Characteristics } & \multirow{2}{*}{$\begin{array}{l}\text { Scoring } \\
\text { system }\end{array}$} & \multirow{2}{*}{$\begin{array}{c}\text { Range } \\
\text { Observed } \\
\text { (possible) }\end{array}$} & \multirow[b]{2}{*}{ Categories } & \multicolumn{2}{|c|}{ Respondent } & \multirow[b]{2}{*}{ Mean } & \multirow[b]{2}{*}{ SD* } \\
\hline & & & & $\begin{array}{c}\text { Number } \\
(n=90)\end{array}$ & $\begin{array}{c}\text { Percent } \\
(\%)\end{array}$ & & \\
\hline \multirow[t]{3}{*}{ Age } & \multirow[t]{3}{*}{ Actual years } & \multirow{3}{*}{$\begin{array}{c}28-66 \\
\text { (Unknown) }\end{array}$} & Young (up to 35) & 7 & 7.7 & \multirow{3}{*}{47.77} & \multirow{3}{*}{7.97} \\
\hline & & & Middle age (36-50) & 51 & 46.6 & & \\
\hline & & & Old $(>50)$ & 42 & 45.7 & & \\
\hline \multirow[t]{3}{*}{ Level of education } & \multirow{3}{*}{$\begin{array}{c}\text { Years of } \\
\text { schooling }\end{array}$} & \multirow{3}{*}{$\begin{array}{c}2-8 \\
\text { (Unknown) }\end{array}$} & Sign only $(0.5)$ & 0 & 0 & \multirow{3}{*}{4.96} & \multirow{3}{*}{1.64} \\
\hline & & & Primary (1-5) & 61 & 67.8 & & \\
\hline & & & Secondary (6-10) & 29 & 32.2 & & \\
\hline \multirow[t]{3}{*}{ Household size } & \multirow{3}{*}{$\begin{array}{l}\text { No. of } \\
\text { members }\end{array}$} & \multirow{3}{*}{$\begin{array}{c}2-9 \\
\text { (Unknown) }\end{array}$} & Small (2-4) & 36 & 29.9 & \multirow{3}{*}{5.12} & \multirow{3}{*}{1.67} \\
\hline & & & Medium (5-6) & 35 & 38.9 & & \\
\hline & & & Large $(>6)$ & 19 & 31.2 & & \\
\hline \multirow[t]{3}{*}{ Farm size } & \multirow[t]{3}{*}{ Hectares } & \multirow{3}{*}{$\begin{array}{c}0.001-11 \\
\text { (Unknown) }\end{array}$} & Small $(<0.05)$ & 20 & 22.2 & \multirow{3}{*}{0.47} & \multirow{3}{*}{1.19} \\
\hline & & & Medium (0.05-3.0) & 34 & 35.3 & & \\
\hline & & & large $(>3.0)$ & 36 & 42.5 & & \\
\hline \multirow{3}{*}{$\begin{array}{l}\text { Annual family } \\
\text { income }\end{array}$} & \multirow[t]{3}{*}{ '000 TK } & $7.5-350$ & Low $(\leq 60)$ & 18 & 19.8 & & \\
\hline & & (Unknown) & Medium (61-100) & 43 & 47.4 & 91.67 & 49.56 \\
\hline & & & High $(>100)$ & 29 & 32.8 & & \\
\hline Fish culture & Days & $3-38$ & Short term $(<5)$ & 5 & 5.6 & & \\
\hline experience & & (Unknown) & Midterm (5-15) & 5 & 5.5 & 24.56 & 8.30 \\
\hline & & & Long-term $(>15)$ & 80 & 88.9 & & \\
\hline Training exposure & Days & $0-20$ & Short term $(<5)$ & 82 & 91.2 & & \\
\hline & & (Unknown) & Midterm (5-10) & 5 & 5.5 & 2.58 & 3.00 \\
\hline & & & Long term $(>10)$ & 3 & 3.3 & & \\
\hline Credit received & '000 TK & $0-150$ & Low $(<40)$ & 79 & 87.9 & & \\
\hline & & (Unknown) & Medium (40-80) & 10 & 11 & 15.47 & 21.91 \\
\hline & & & High $(>80)$ & 1 & 1.1 & & \\
\hline Communication & Score & $4-23$ & Low $(<10)$ & 27 & 66.8 & & \\
\hline exposure & & $(0-36)$ & Medium (10-20) & 60 & 29.9 & 11.54 & 4.33 \\
\hline & & & $\operatorname{High}(>20)$ & 3 & 3.3 & & \\
\hline Knowledge in & Score & $10-20$ & Low $(<8)$ & 0 & 0 & & \\
\hline managing fish & & $(0-20)$ & Medium (8-16) & 4 & 4.4 & 18.99 & 1.40 \\
\hline sanctuary & & & High $(>15)$ & 86 & 95.6 & & \\
\hline
\end{tabular}

Source: Field survey, 2013 
Data presented in Table 1 indicated that majority (46.6 percent) of the fishermen were middle aged having average level of education 4.96. Most of the fishermen (38.9 percent) had medium household size with large farm size ( $>3 \mathrm{ha}$ ). Average annual family income was Tk 91.67 thousand. They have long term ( $>15$ days) fish culture experience and short term $(<5$ days $)$ training exposure. They took loan from different credit providing organization with an average Tk 15.47 thousand. They posses low communication exposure status with an average score 11.54 and average knowledge in managing fish sanctuary score 18.99.

Fishermen's Awareness in Managing Fish Sanctuary Fishermen's awareness in managing fish sanctuary was the main thrust of this research. The awareness score of the fishermen ranged from 44 to 66 against the possible score 0 to 80 with an average score of 57.08 and standard deviation 4.55. The fishermen were categorized into three categories based on their awareness scores as shown in Table 2.

Table 2. Distribution of the fishermen based on their awareness score

\begin{tabular}{|c|c|c|c|c|c|c|}
\hline \multirow{2}{*}{$\begin{array}{c}\text { Possible } \\
\text { score }\end{array}$} & \multirow{2}{*}{$\begin{array}{c}\text { Observed } \\
\text { score }\end{array}$} & \multirow[t]{2}{*}{ Categories } & \multicolumn{2}{|c|}{ Fishermen } & \multirow[t]{2}{*}{ Mean } & \multirow[t]{2}{*}{ SD } \\
\hline & & & No. & $\%$ & & \\
\hline \multirow{4}{*}{$0-80$} & \multirow{4}{*}{$44-66$} & Low awareness $(<25)$ & 0 & 0 & \multirow{4}{*}{57.08} & \multirow{4}{*}{4.55} \\
\hline & & Medium awareness (25-50) & 67 & 74.5 & & \\
\hline & & High awareness $(>50)$ & 23 & 25.5 & & \\
\hline & & Total & 90 & 100 & & \\
\hline
\end{tabular}

Source: Field survey, 2013

Data presented in Table 2 reveals that, $74.5 \%$ of the fishermen had medium awareness, 25.5\% had high awareness and no respondents were found under the category low awareness in managing fish sanctuary.

Awareness score for each statement was calculated by using the awareness index (AI) and the mean score of each statement was also calculated. The AI for each statement has been arranged in rank order according to their extent of agreement which appears in Table 3.

Data presented in Table 3 reveals that fishermen, who work in this sanctuary they were not fully aware in managing fish sanctuary, they had medium level of awareness (74.5\%). Among 20 statements "A series of bamboo cage like structures are being used to protect fish from poaching as well as to protect small fish from predation by bigger fish", "In some places RCC tetrapods and pipes are used for an extra and long-term protection." and "Selected area should be marked with distinguishable symbols (e.g. red flag, tree, bazaar etc.)" were highest score awareness statement and ranked 1, 2 and 3 respectively. Hence, other aspects should be considered carefully to increase their level of awareness.

Relationship between the selected Characteristics of the fishermen and their awareness in managing fish sanctuary

To explore the relationship, Pearson's product moment correlation was conducted between awareness of the fishermen in managing fish sanctuary and their selected characteristics have been shown in Table 4 .

The findings indicated that age, level of education, fish culture experience, communication exposure and Knowledge in managing fish sanctuary had significant positive relationship with the awareness of the fishermen in managing fish sanctuary.

Age had significant positive relationship with the awareness. The main reason for this result might be that the old respondent has more experience and 
communication facility than youngers which leads to have more awareness. Karim (1994) found that age of the farmers had positive and significant correlations with their awareness.

Table 3. Statement-wise score in awareness $(n=90)$

\begin{tabular}{|c|c|c|c|c|c|c|c|c|}
\hline \multirow[t]{2}{*}{ Aspects } & \multicolumn{4}{|c|}{ Extent of Awareness } & & \multirow[t]{2}{*}{$\mathrm{AI}$} & \multirow[t]{2}{*}{$\mathrm{M}$} & \multirow[t]{2}{*}{$\mathrm{RO}$} \\
\hline & $\begin{array}{l}\mathrm{VH} \\
(4)\end{array}$ & $\begin{array}{c}\mathrm{H} \\
(3)\end{array}$ & $\begin{array}{l}\mathrm{M} \\
(2)\end{array}$ & $\begin{array}{l}\mathrm{L} \\
(1)\end{array}$ & $\begin{array}{l}\mathrm{N} \\
(0)\end{array}$ & & & \\
\hline $\begin{array}{l}\text { Fish sanctuary is to be a part of sustainable use of fishery } \\
\text { resources. }\end{array}$ & 27 & 58 & 5 & 0 & 0 & 292 & 3.24 & 5 \\
\hline Fish sanctuary should be deepest part of the river or beel. & 30 & 35 & 24 & 1 & 0 & 274 & 3.04 & 7 \\
\hline Relatively low water current is found in fish sanctuary. & 23 & 30 & 30 & 7 & 0 & 249 & 2.77 & 12 \\
\hline $\begin{array}{l}\text { The place of fish sanctuary should have less probability } \\
\text { of siltation. }\end{array}$ & 8 & 22 & 48 & 12 & 0 & 206 & 2.29 & 18 \\
\hline The transportation route of river should not be hampered. & 10 & 33 & 40 & 7 & 0 & 226 & 2.51 & 16 \\
\hline $\begin{array}{l}\text { The place of fish sanctuary should be safe from human } \\
\text { interference. }\end{array}$ & 5 & 33 & 40 & 12 & 0 & 211 & 2.34 & 17 \\
\hline $\begin{array}{l}\text { Size/Area of fish sanctuary is positively related with the } \\
\text { size of target fish sp. }\end{array}$ & 18 & 52 & 19 & 1 & 0 & 267 & 2.97 & 9 \\
\hline $\begin{array}{l}\text { Fish sanctuary is an important habitat for endangered fish } \\
\text { species. }\end{array}$ & 37 & 44 & 9 & 0 & 0 & 298 & 3.31 & 4 \\
\hline $\begin{array}{l}\text { A series of bamboo cage like structures are being used to } \\
\text { protect fish from poaching as well as to protect small fish } \\
\text { from predation by bigger fish. }\end{array}$ & 58 & 31 & 1 & 0 & 0 & 327 & 3.63 & 1 \\
\hline $\begin{array}{l}\text { In some places RCC tetra-pods and pipes are used for an } \\
\text { extra and long-term protection. }\end{array}$ & 57 & 26 & 7 & 0 & 0 & 320 & 3.56 & 2 \\
\hline $\begin{array}{l}\text { Selected area should be marked with distinguishable } \\
\text { symbols (e.g. red flag, tree, bazaar etc.) }\end{array}$ & 50 & 35 & 4 & 1 & 0 & 314 & 3.49 & 3 \\
\hline $\begin{array}{l}\text { Fish sanctuary helps to protect breeding and nursery } \\
\text { ground and to produce brood fish and other fish. }\end{array}$ & 18 & 52 & 17 & 3 & 0 & 265 & 2.94 & 10 \\
\hline $\begin{array}{l}\text { King fish, Egret, Bittern and Hawk indirectly helps to } \\
\text { maintain the aquatic ecosystem in fish sanctuary. }\end{array}$ & 5 & 43 & 42 & 2 & 0 & 235 & 2.61 & 15 \\
\hline $\begin{array}{l}\text { Fish sanctuary enhanced and preserving aquatic } \\
\text { biodiversity. }\end{array}$ & 7 & 49 & 31 & 3 & 0 & 240 & 2.67 & 14 \\
\hline $\begin{array}{l}\text { Fish sanctuary is an effective tool for conserving fish } \\
\text { stock. }\end{array}$ & 24 & 45 & 20 & 1 & 0 & 272 & 3.02 & 8 \\
\hline $\begin{array}{l}\text { Fish sanctuary lead to peaceful life without any } \\
\text { disturbance. }\end{array}$ & 16 & 50 & 22 & 2 & 0 & 260 & 2.89 & 11 \\
\hline $\begin{array}{l}\text { Place size of fish sanctuary should be selected by } \\
\text { considering opinion of local fishermen and their } \\
\text { livelihood. }\end{array}$ & 24 & 50 & 16 & 0 & 0 & 278 & 3.08 & 6 \\
\hline $\begin{array}{l}\text { It helps to increase the abundance of threatened fish } \\
\text { species. }\end{array}$ & 11 & 45 & 35 & 0 & 0 & 249 & 2.77 & 12 \\
\hline $\begin{array}{l}\text { Water hyacinth or other aquatic vegetation also be used } \\
\text { to create a suitable refuge for fish. }\end{array}$ & 12 & 42 & 34 & 1 & 0 & 243 & 2.70 & 13 \\
\hline $\begin{array}{l}\text { Algae grow on the tree branches or on bamboos, and that } \\
\text { is an extra attraction for fish to congregate. }\end{array}$ & 29 & 25 & 33 & 3 & 0 & 260 & 2.89 & 11 \\
\hline
\end{tabular}

Source: Field survey, 2013, Here, VH=Very High; H= High; M= Medium; L=Low; AI=Awareness Index; M=Mean and $\mathrm{RO}=$ Rank Order. 
Table 4. Coefficient of correlation (r) between explanatory and focus variables

\begin{tabular}{|c|c|c|c|c|}
\hline \multirow{2}{*}{$\begin{array}{l}\text { Focus } \\
\text { Variables }\end{array}$} & \multirow[t]{2}{*}{ Characteristics of the fishermen } & \multirow{2}{*}{$\begin{array}{c}\text { Computed r } \\
\text { values for } \\
\text { fishermen }\end{array}$} & \multicolumn{2}{|c|}{ Tabulated r value with 88 d.f. } \\
\hline & & & 0.05 level & 0.01 level \\
\hline \multirow{10}{*}{$\begin{array}{l}\text { Awareness of } \\
\text { the fishermen } \\
\text { in managing } \\
\text { fish sanctuary }\end{array}$} & Age & $0.317^{* *}$ & \multirow{10}{*}{0.208} & \multirow{10}{*}{0.271} \\
\hline & Level of education & $0.922^{* *}$ & & \\
\hline & Household size & 0.055 & & \\
\hline & Farm size & 0.110 & & \\
\hline & Annual family income & 0.130 & & \\
\hline & Fish culture experience & $0.593^{* *}$ & & \\
\hline & Training exposure & 0.102 & & \\
\hline & Credit received & 0.084 & & \\
\hline & Communication exposure & $0.353^{* *}$ & & \\
\hline & $\begin{array}{l}\text { Knowledge in managing fish } \\
\text { sanctuary }\end{array}$ & $0.247^{*}$ & & \\
\hline
\end{tabular}

Source: Field survey, 2013, Note: ${ }^{*}$ Correlation is significant at $5 \%$ level of probability, ${ }^{* *}$ Correlation is significant at $1 \%$ level of probability

Level of education had significant positive relationship with the awareness. This finding means that increased education of the fishermen led to have high awareness in managing fish sanctuary. Education is the process of development of mind of an individual and it increases his power of observation, understanding, decision making and adjustment to new situation. It makes individual to become rational, conscious and get useful information to their day to day problem through different sources of information such as reading leaflets, books, magazines, journals and other printing materials. Consequently, their outlook is broadened, horizon of knowledge is expanded and innovativeness is increased. Reza (2005) also found that the post harvest quality loss of the fishes needs to be minimized by improving the handling, transportation and preservation through creating awareness among various actors and infrastructure development.

Fish culture experience, communication exposure and Knowledge in managing fish sanctuary had significant positive relationship with the awareness. With the increase of fish culture experience awareness of the fishermen also increases which helps them to acquire more knowledge through increasing communication exposure. Communication exposure and knowledge in managing fish sanctuary enable an individual to gain more information and broaden his outlooks. High communication and knowledge means more fishermen being enlightened and consequently having broader outlooks and progressive awareness. Shanto (2011) found that the farming experience of the fishermen had a significant positive relationship with their awareness on environmental pollution due to use of pesticides in vegetable cultivation.

\section{Conclusions}

The study reveals that, 74.5 percent of the fishermen had medium awareness while 25.5 percent of them had high level of awareness in managing fish sanctuary. To increase awareness effective steps should be taken by the Department of Fisheries (DoF) and NonGovernment Organization (NGOs) for strengthening fisheries extension service by regular training, field visit for motivation of fishermen to increase their awareness in managing fish sanctuary. Age, level of education, fish culture experience, communication exposure and Knowledge in managing fish sanctuary 
had significant positive relationship with the awareness of the fishermen in managing fish sanctuary. Hence, in planning any program to increase fishermen's level of awareness, all of these aspects should be considered by the respective authority. Beside these, the fisheries extension workers could easily motivate the respondents through using different mass media like radio and television as useful communication media in respects of technology dissemination which ultimately leads to increase fishermen awareness towards managing fish sanctuary.

\section{References}

BBS (2011). Statistical Yearbook of Bangladesh. Bangladesh Bureau of Staististics, Statistical Division, Government of the Peoples Republic of Bangladesh, Dhaka, pp 90-110.

DoF (2010). Saranica, Matsya Pakhya Sankalan, Annual Report, Ministry of Fisheries and Livestock. The Government of Peoples Republic of Bangladesh, Dhaka, $120 \mathrm{pp}$.
Karim ANMR (1994). Insect Management in Bangladesh. A paper presented at the joint PABGIFAP Asia Working Group Meeting, 3-5 May, 1994, Dhaka.

Reza SM (2005). Presentation of Drying Activities of Marine Fisheries in the Coastal Region of Bangladesh. Bangladesh Journal of Fisheries, 6 (27), 46-50.

Saha SK (2004). Socio-economic Aspects of Aquaculture in Tangail Sadar Upazila (unpublished master's thesis). Department of Aquaculture, Bangladesh Agricultural University, Mymensingh. $77 \mathrm{pp}$.

Shanto HH (2011). Awareness of the Farmers on Environmental Pollution Due to Use of Pesticides in Vegetables Cultivation (unpublished master's thesis). Department of Agricultural Extension Education, Bangladesh Agricultural University, Mymensingh. 